\title{
Differential and Tissue-specific Regulation of the Multiple Rat c-erbA Messenger RNA Species by Thyroid Hormone
}

Richard A. Hodin, Mitchell A. Lazar, ${ }^{\star}$ and William W. Chin

Division of Genetics, Department of Medicine, Brigham and Women's Hospital; Howard Hughes Medical Institute; and Harvard Medical School, Boston, Massachusetts 02115; and *University of Pennsylvania

School of Medicine, Endocrine Section, Philadelphia, Pennsylvania 19104

\begin{abstract}
Thyroid hormone $\left(T_{3}\right)$ has been shown to regulate the level of its receptor in a number of tissues and cell lines. Recently, proteins encoded by the protooncogene c-erbA have been identified as $T_{3}$ receptors. In the rat, four c-erbA gene products have been isolated, three of which, $r$-erbA $\alpha-1, r-\operatorname{erbA} \beta-1$, and r-erbA $\beta-2$, encode biologically active $T_{3}$ receptors; the fourth, r-erbA $\alpha-2$, may play an inhibitory role in $T_{3}$ action. The present work examines the molecular nature of $T_{3}$ receptor autoregulation using probes specific for each c-erbA mRNA. Rats were rendered hypothyroid with propylthiouracil and then treated with either saline or $T_{3}$. Northern blot analyses reveal marked tissue-specific and differential regulation of the multiple c-erbA mRNAs by $T_{3}$. In the pituitary the levels of $r$ erbA $\beta-1$ mRNA increase, whereas the levels of the pituitaryspecific r-erbA $\beta-2$ mRNA decrease with $T_{3}$ treatment. In heart, kidney, liver, and brain the levels of r-erbA $\beta-1$ are unaffected by thyroidal status. The levels of both r-erbA $\alpha$ mRNAs decrease with $T_{3}$ treatment in all tissues examined except for the brain, where there is no change. In addition, we find that changes in the mRNAs encoding specific subpopulations of $T_{3}$ receptors do not always parallel changes in total nuclear $T_{3}$ binding. Differential regulation of the specific c-erbA mRNA species could have important consequences for $T_{3}$ action. ( $J$. Clin. Invest. 1990. 85:101-105.) hormone regulation - pituitary gland • receptor autoregulation • thyroid hormone action • thyroid hormone receptors
\end{abstract}

\section{Introduction}

The magnitude of the cellular response to thyroid hormone $\left(T_{3}\right)^{1}$ is related to the number of nuclear receptors present (1). It is therefore likely that physiologic or pharmacologic alterations in receptor number may modify the response of a tissue

Dr. Hodin's present address is Beth Israel Hospital, Department of Surgery, 330 Brookline Avenue, Boston, MA 02146.

Please address correspondence to Dr. Richard A. Hodin, Thorn Research Building, Room 917, Brigham and Women's Hospital, 75 Francis Street, Boston, MA 02115.

Received for publication 25 May 1989 and in revised form $30 \mathrm{Au}$ gust 1989.

1. Abbreviations used in this paper: PTU, propylthiouracil; RA, retinoic acid; $\mathrm{T}_{3}$, triiodothyronine.

J. Clin. Invest.

(c) The American Society for Clinical Investigation, Inc.

0021-9738/90/01/0101/05 \$2.00

Volume 85, January 1990, 101-105 to $T_{3}$. In $\mathrm{GH}_{1}$ cells, a rat pituitary tumor-derived cell line, $T_{3}$ treatment causes a decrease in receptor number which, in turn, results in an attenuation in $T_{3}$ responsiveness, as measured by growth hormone gene transcription (2).

Numerous investigators have studied the effects of thyroidal status on rat $T_{3}$ receptors, but the results have been conflicting. Pituitary receptor levels have been reported to increase (3), decrease (4), or remain unchanged (5) in response to $T_{3}$ treatment. Similar inconsistencies exist in the literature concerning the effect of thyroidal status on receptor number in rat liver $(6,7)$.

$\mathrm{T}_{3}$ receptors, encoded by the $\alpha$ and $\beta$ c-erbA genes, are members of a superfamily of structurally related receptor proteins $(8,9)$. The recent identification of multiple forms of the $T_{3}$ receptor (10-18) sheds new light on the issue of receptor autoregulation. We have shown, for example, that changes in specific receptor subpopulations may not be reflected in a measurement of total receptor number in $\mathrm{GH}_{3}$ cells (14, $18,19)$.

In the rat, three putative biologically active $T_{3}$ receptors have been identified, r-erbA $\alpha-1$ (10), r-erbA $\beta-1$ (13), and rerbA $\beta-2$ (18). In addition, a related molecule, r-erbA $\alpha-2$, does not bind $T_{3}(12,14,15)$ and may act to inhibit $T_{3}$ action (20). $\mathrm{r}$-erbA $\alpha-1, \mathrm{r}$-erbA $\alpha-2$, and r-erbA $\beta-1$ are expressed to varying degrees in a number of rat tissues $(14,18)$, whereas the expression of r-erbA $\beta-2$ is limited to the anterior pituitary gland (18).

We have examined the effects of $T_{3}$ treatment on the levels of the various c-erbA gene products in pituitary as well as a number of other rat tissues. Our results show that there is tissue-specific and differential regulation of the r-erbA mRNAs by thyroid hormone, and suggest that measurement of total nuclear $\mathrm{T}_{3}$ binding is inadequate when examining alterations in $T_{3}$ receptors.

\section{Methods}

Adult male Sprague-Dawley rats $(125-150 \mathrm{~g})$ were maintained on standard chow and water supplemented with $0.05 \%(\mathrm{wt} / \mathrm{vol})$ propylthiouracil (PTU) for a 6-wk period. Six daily intraperitoneal injections of either saline (PTU only or hypothyroid group) or $20 \mu \mathrm{g} / \mathrm{g}$ body weight triiodothyronine (PTU $+\mathrm{T}_{3}$ or hyperthyroid group) were then administered. During the administration of the supraphysiologic replacement dose of $T_{3}$ both groups of animals were maintained on PTU treatment. The animals were killed by decapitation and their organs were removed, immediately frozen in liquid nitrogen, and stored at $-70^{\circ} \mathrm{C}$. Blood was collected from each animal and assayed for $T_{3}$ to confirm thyroidal status.

The frozen tissues were homogenized and RNA was extracted using the guanidinium thiocyanate method (21). Northern blot analyses were performed by standard techniques (22). The filters were hybridized with cDNA (growth hormone, actin, and spot-14 mRNAs) or cRNA (r-erbA mRNAs) probes labeled with ${ }^{32} \mathrm{P}$, typically to a specific activity of $\sim 5 \times 10^{8} \mathrm{cpm} / \mu \mathrm{g}$ DNA. The r-erbA $\beta$ mRNA probes are 
Figure 1. Effect of thyroidal status on pituitary r-erbA $\beta$ mRNA levels. Northern analyses were performed on pituitary RNA derived from PTU only (hypo.) and PTU plus $\mathrm{T}_{3}$ treated (hyper.) rats. 10

$r$-erbA $\beta-1$

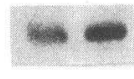

$\mu \mathrm{g}$ of total RNA was loaded in each lane.

The autoradiograms shown are from a single experiment representative of six experiments performed. The r-erbA $\beta$ probes are cRNA derived and identical to those described previously (18). The $\beta$ actin and growth hormone probes are CDNA derived.

derived from the $5^{\prime}$ region of the cDNAs and have been previously shown to be specific for either the r-erbA $\beta$ - 1 or $\mathrm{r}$-erbA $\beta$ - 2 species (18). The r-erbA $\alpha$ probe is derived from the region common to the $r$ erbA $\alpha-1$ and r-erbA $\alpha-2$ mRNAs. We have previously determined the specificity of the 2.6- $(\alpha-2)$ and 5-kb $(\alpha-1)$ hybridizing bands (14). Conditions for hybridization were as follows: cDNA probes, $5 \times$ standard saline citrate (SSC)/50\% (vol/vol) formamide/1\% (wt/vol) SDS at $42^{\circ} \mathrm{C}$; cRNA probes, $5 \times \mathrm{SSC} / 50 \%$ formamide $/ 5 \%$ SDS at $65^{\circ} \mathrm{C}$. Washing conditions were: cDNA probes, $2 \times \mathrm{SSC} / 0.1 \%$ SDS at $50^{\circ} \mathrm{C}$; cRNA probes, $0.2 \times \mathrm{SSC} / 0.1 \% \mathrm{SDS}$ at $65^{\circ} \mathrm{C}$. Relative changes in mRNA levels were determined by laser densitometry of autoradiograms and normalized for $\beta$-actin mRNA. Statistical analyses were performed using the unpaired $t$ test.

Nuclear extracts were prepared from either fresh or frozen tissues for the $T_{3}$ binding experiments. Tissues were homogenized in STM buffer $\left(0.25 \mathrm{M}\right.$ sucrose, $0.02 \mathrm{M}$ Tris, $\left.1.1 \mathrm{mM} \mathrm{MgCl}_{2}, \mathrm{pH} 7.85\right)$ and the homogenate centrifuged at $2,000 \mathrm{rpm}$ at $4^{\circ} \mathrm{C}$. The nuclear pellet was washed twice with STM buffer plus $0.2 \%$ (vol/vol) Triton X-100 and then with STM buffer plus $0.1 \mathrm{mM}$ EDTA and $0.5 \mathrm{mM}$ DTT. The nuclear pellet was then incubated for $30 \mathrm{~min}$ in a buffer containing 0.6 $\mathrm{M} \mathrm{KCl}, 20 \mathrm{mM}$ Hepes (pH 7.3), $20 \mu \mathrm{M} \mathrm{ZnCl}_{2}, 0.2 \mathrm{mM}$ EGTA, and 0.5 M DTT. After centrifugation at $27,000 \mathrm{rpm}$ for $30 \mathrm{~min}$ the supernatant (nuclear extract) was collected. Protein content was determined using the method of Bradford (23).

$2 \mu \mathrm{g}$ protein extract was incubated with $0.05 \mathrm{nM}\left[{ }^{125} \mathrm{I}\right] \mathrm{T}_{3}$ plus varying amounts of unlabeled $\mathrm{T}_{3}$ at $4^{\circ} \mathrm{C}$ for $16 \mathrm{~h}$. Bound and free hormones were separated using a Sephadex G-50 column and radioactivity was measured by gamma spectrometry.

\section{Results}

r-erbA $\beta-1$ and r-erbA $\beta-2$ mRNA levels in pituitary glands of hypothyroid and hyperthyroid rats were determined using specific probes (18). A representative Northern blot analysis demonstrating that the two $\beta$ forms of r-erbA are differentially regulated by $T_{3}$ in the pituitary is shown in Fig. 1 . After normalization for $\beta$-actin mRNA, the r-erbA $\beta$ - 1 mRNA levels were shown to increase $\sim 3.5$-fold $(P<0.025)$, whereas the r-erbA $\beta$-2 levels decreased $\sim 50 \%(P<0.005)$ from the hypothyroid to the hyperthyroid state. In agreement with previous work (24), growth hormone mRNA levels increased $~ 15$-fold with $\mathrm{T}_{3}$ treatment.

In contrast to the changes seen in the pituitary, the levels of r-erbA $\beta-1$ mRNA were unchanged in brain, heart, and kidney as a function of thyroidal status (Fig. 2). In liver there appeared to be more variability in $\mathrm{r}$-erbA $\beta-1$ expression. After correction for $\beta$-actin expression there was a tendency towards a decrease in r-erbA $\dot{\beta}-1$ mRNA levels with $T_{3}$ treatment, although this was not statistically significant. Spot 14 mRNA was significantly increased in all livers from hyperthyroid rats (data not shown). In agreement with our previous studies (18) no hybridization corresponding to the r-erbA $\beta-2$ mRNA was detected in these nonpituitary tissues.

The r-erbA $\alpha-1$ ( $5 \mathrm{~kb}$ in size) and r-erbA $\alpha-2$ (2.6 kb in size) mRNAs were also studied in these various rat tissues using a probe that hybridizes to both mRNAs (14). Both the r-erbA $\alpha-i$ and r-erbA $\alpha-2$ mRNA levels decreased with $\mathrm{T}_{3}$ treatment in all tissues studied with the exception of brain (Fig. 3). The magnitudes of the decreases in r-erbA $\alpha-1$ were $\sim 65,69$, and $22 \%$ of hypothyroid levels in heart $(P<0.005)$, kidney $(P<0.005)$, and pituitary $(P<0.1)$, respectively. The decreases in $\mathrm{r}$ erbA $\alpha-2$ mRNA were similar in magnitude to those seen with r-erbA $\alpha-1: 86 \%$ in heart $(P<0.005), 63 \%$ in kidney $(P$ $<0.005)$, and $22 \%$ in pituitary $(P<0.1)$. The levels of both r-erbA $\alpha$ mRNAs remained constant in brain regardless of thyroidal status. Rat liver contains minimal amounts of $r$ erbA $\alpha$ mRNAs; hence, a quantitative analysis was not possible. A 6-kb band, which we have previously shown to hybridize to both $\alpha$-1- and $\alpha$-2-specific probes (14) and which may represent an unspliced heteronuclear RNA, is evident in all rat tissues examined. The level of this 6-kb band also decreases with $\mathrm{T}_{3}$ treatment.

$\mathrm{T}_{3}$ binding studies were performed using nuclear extracts from pituitary glands of hypothyroid and hyperthyroid animals. Fig. 4 illustrates Scatchard analyses showing no change in the affinity constant $\left(K_{d}=0.7 \mathrm{nM}\right)$ between the two groups.

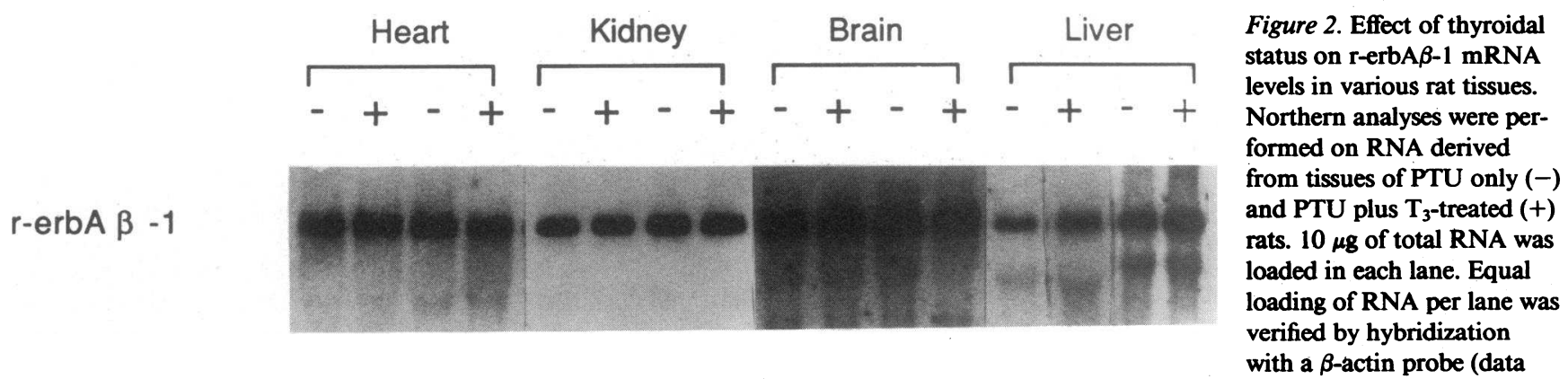

not shown). The autoradiograms shown are representative of experiments repeated at least four times in each case. The probe is identical to that used in Fig. 1. 


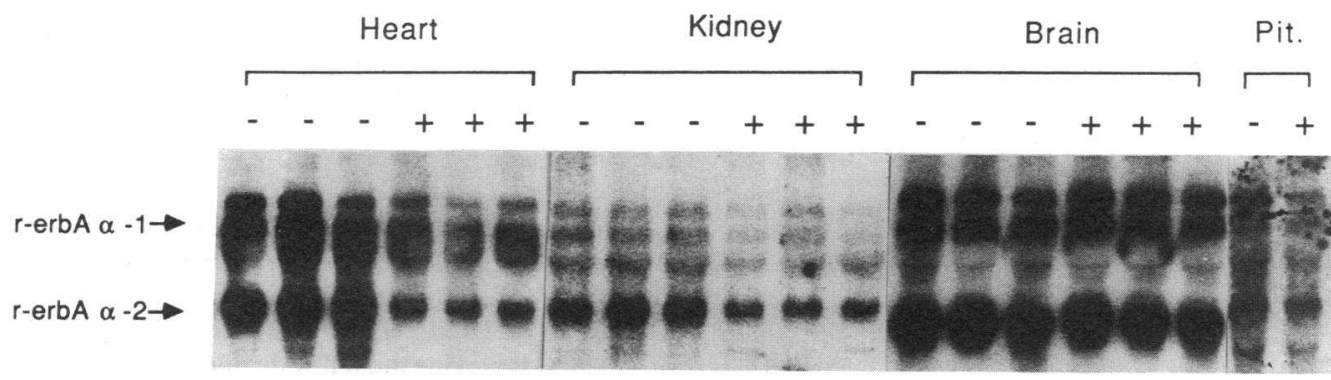

Figure 3. Effect of thyroidal status on r-erbA $\alpha$ mRNA levels in various rat tissues. Northern analyses were performed on RNA derived from tissues of PTU only (-) and PTU plus $T_{3}$-treated $(+)$ rats. $10 \mu \mathrm{g}$ of total RNA was loaded in each lane. A cRNA probe that detects both $\mathrm{r}$ erbA $\alpha-1(5 \mathrm{~kb})$ and $\mathrm{r}$-erbA $\alpha$ $2(2.6 \mathrm{~kb}) \mathrm{mRNAs}$ was used (14). A 6-kb band, detected Actin

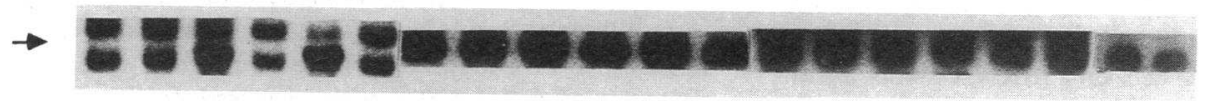
in all tissues examined, is discussed in the text. Faint nonspecific hybridization

with rRNA is also evident. Hybridization with the $\beta$-actin control is depicted. The r-erbA $\alpha$ probe is cRNA derived and includes the region common to the r-erbA $\alpha-1$ and r-erbA $\alpha-2$ cDNAs. The $\beta$-actin probe is a cDNA probe.

The maximum binding capacity increased slightly with $T_{3}$ treatment $(0.55 \pm 0.01 \mathrm{fmol} / \mu \mathrm{g}$ protein $)$ compared with hypothyroid controls $(0.42 \pm 0.03 \mathrm{fmol} / \mu \mathrm{g}$ protein; $P=0.1)$. No significant changes in either affinity or maximum binding capacity were seen in nuclear extracts from hypo- and hyperthyroid liver, kidney, brain, or heart (data not shown).

\section{Discussion}

The recent identification of multiple forms of the $T_{3}$ receptor, as well as a related protein that appears to inhibit hormone action, has dictated a change in our understanding of the mechanisms of $T_{3}$ action. Since various subpopulations of $T_{3}$ receptors may be differentially regulated by $T_{3}(18)$, previous studies on receptor autoregulation in which total nuclear $T_{3}$ binding was measured may have failed to detect significant alterations in specific $T_{3}$ receptors.

Our results indicate that thyroidal status differentially affects the expression of the various r-erbA mRNAs, and possibly their products, and that these effects differ from tissue to tissue. In the pituitary gland, as in $\mathrm{GH}_{3}$ cells (18), r-erbA $\beta$ - 1 levels increase, whereas r-erbA $\beta-2$ levels decrease with $T_{3}$ treatment. The increase in r-erbA $\beta-1$ mRNA appears to be greater than in the $\mathrm{GH}_{3}$ cell model. This difference may relate

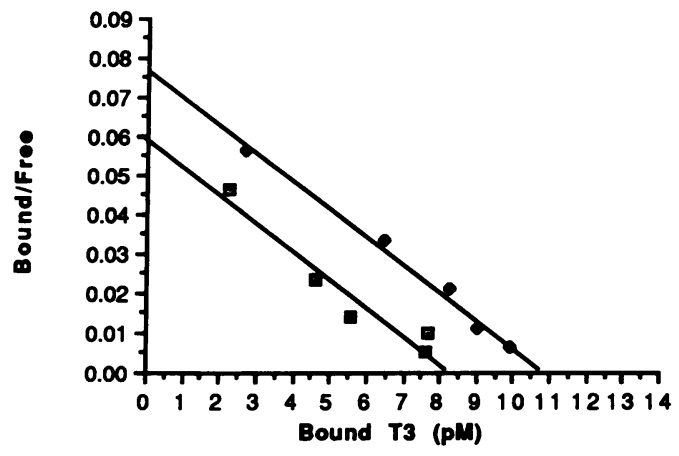

Figure 4. Effect of thyroidal status on $\mathrm{T}_{3}$ binding in pituitary nuclear extracts. Scatchard plots from $\mathrm{T}_{3}$ binding experiments on pituitary nuclear extracts derived from PTU only (hypothyroid, open squares) and PTU plus $\mathrm{T}_{3}$-treated (hyperthyroid, solid squares) rats are shown. Each point represents the average of duplicate samples. The nuclear extracts are pooled from six animals in each case. to characteristics of the $\mathrm{GH}_{3}$ cell culture system or to differences in experimental protocol, such as the duration and magnitude of $\mathrm{T}_{3}$ exposure. However, in kidney, heart, brain, and liver, the levels of r-erbA $\beta-1$ are unaffected by thyroidal status.

The levels of both r-erbA $\alpha$ species decrease with $T_{3}$ treatment in all tissues examined with the exception of brain. In each tissue, the magnitudes of the change in the two r-erbAa mRNA species were approximately the same. This downregulation of r-erbA $\alpha$ mRNAs is similar to what we have previously shown in $\mathrm{GH}_{3}$ cells $(14,19)$. The magnitude of the r-erbA $\alpha$ mRNA decreases were greatest in heart and kidney and less in pituitary.

Table I summarizes the effects of thyroidal status on the r-erbA species in the rat tissues we have examined. Of note, the absence of a $T_{3}$ effect on any r-erbA mRNA in brain is consistent with its general lack of responsiveness to $T_{3}$ and may relate to the abundance of the mRNA encoding $r-\operatorname{erbA} \alpha-2$, a potential inhibitor of $T_{3}$ action (20). Table I also illustrates that the pituitary appears to be unique both in its expression of the r-erbA $\beta-2$ mRNA and the induction of the r-erbA $\beta-1$ mRNA with $T_{3}$ treatment. These data suggest a possible role for $\mathrm{r}-$ $\operatorname{erbA} \beta-2$ in the regulation of $\mathrm{r}$-erbA $\beta$ - 1 expression.

The slight increase in $\mathrm{T}_{3}$ binding in pituitary nuclear extracts from $T_{3}$-treated rats is consistent with data from the Northern analyses, inasmuch as the changes in specific r-erbA $m R N A s$ are in different directions. The decrease in $T_{3}$ binding seen in the GH cell model compared with the data we obtained in rat pituitary may relate to the relatively greater increase in r-erbA $\beta-1$ mRNA and more moderate decrease in r-erbA $\beta-2$ mRNA in this tissue in the whole animal. Since the total $T_{3}$

Table I. Effects of Thyroidal Status on r-erbA mRNA Levels

\begin{tabular}{lcccc}
\hline & r-erbA $\beta-1$ & r-erbA $\beta-2$ & r-erbA $\alpha-1$ & r-erbA $\alpha-2$ \\
\hline Heart & No change & N/A & $-65 \%$ & $-86 \%$ \\
Kidney & No change & N/A & $-69 \%$ & $-63 \%$ \\
Liver & No change & N/A & $*$ & $*$ \\
Brain & No change & N/A & No change & No change \\
Pituitary & $+341 \%$ & $-43 \%$ & $-22 \%$ & $-22 \%$ \\
& & & & \\
\hline
\end{tabular}

N/A, Not applicable; r-erb $\beta-2$ mRNA is not detected. *, Levels are too low to be quantitative. 
receptor pool is composed of at least three c-erbA gene products, $\alpha-1, \beta-1$, and $\beta-2$, the conflicting results in the literature on pituitary $T_{3}$ receptor autoregulation may be due to variations in experimental protocol, which could alter the effects on one or more of the receptor subpopulations. The correlation between r-erbA mRNA levels and receptor number may also be affected by posttranscriptional factors such as translational efficiency and/or protein $t_{1 / 2}$.

Although it is difficult to estimate relative abundances of different mRNAs by Northern analyses, it appears that $r-$ $\operatorname{erbA} \beta-1$ is more abundant than $\mathrm{r}$-erbA $\alpha-1$ in the tissues that we have examined. Thus, the lack of a difference in $T_{3}$ binding in hypo- versus hyperthyroid nonpituitary tissues correlates well with the lack of change in r-erbA $\beta-1$ mRNA levels. However, if the specific subpopulations of $T_{3}$ receptors serve different functions, such as interacting with different target genes, then the decrease in r-erbA $\alpha-1$ mRNA could have great consequences for $T_{3}$ action despite the fact that total $T_{3}$ binding does not appear to change. Similarly, the regulation of the mRNA encoding the non-hormone binding r-erbA $\alpha-2$ could be important for $T_{3}$ action, since the protein may function to inhibit $\mathrm{T}_{3}$ responsiveness.

It is possible that factors other than thyroidal status influenced our results. Fasting that leads to significant weight loss, for example, has been shown to be associated with decreased hepatic $T_{3}$ receptor number (25). Although we did not specifically control for food intake, the two groups of rats in our study were of similar weight.

Autoregulation of receptors is a common biological phenomenon seen in higher organisms (26). Various members of the thyroid/steroid hormone receptor superfamily have been shown to either increase or decrease in response to treatment with their cognate hormones (27-33). Similar to what we have shown with $\mathrm{T}_{3}$ receptors, the $\alpha$ and $\beta$ retinoic acid (RA) receptors are differentially regulated by exposure to RA (31). Regulation of the estrogen and glucocorticoid receptors have been shown to be tissue specific $(32,33)$. Studies are in progress to determine if the effects of $T_{3}$ on r-erbA mRNA levels are at the transcriptional level, as is the case with the estrogen and $\beta$-RA receptors $(30,31)$.

Our present model of $\mathrm{T}_{3}$ action includes the interaction of $\mathrm{T}_{3}$ with multiple forms of its receptor, as well as a related protein that appears to inhibit $T_{3}$ action. The present studies demonstrate that experimental conclusions based on total $T_{3}$ nuclear receptor number may be misleading, since receptor subpopulations can be regulated differentially. Further work is clearly needed to determine the role that each of the r-erbA gene products plays in thyroid hormone action.

\section{Acknowledgments}

We thank Dr. Jack Oppenheimer for supplying us with the spot-14 mRNA probe and Kelly Porter for helping in preparation of the manuscript.

\section{References}

1. Samuels, H. H., F. Stanley, and L. E. Shapiro. 1976. Dose-dependent depletion of nuclear receptors by L-triiodothyronine: evidence for a role in induction of growth hormone synthesis in cultured $\mathrm{GH}_{1}$ cells. Proc. Natl. Acad. Sci. USA. 73:3877-3881.
2. Samuels, H. H., F. Stanley, and L. E. Shapiro. 1977. Modulation of thyroid hormone nuclear receptor levels by $3,5,3$ '-triiodo-L-thyronine in $\mathrm{GH}_{1}$ cells. J. Biol. Chem. 252:6052-6060.

3. von Overbeck, K., and Th. Lemarchand-Beraud. 1983. Modulation of thyroid hormone nuclear receptor levels by L-triiodothyronine $\left(\mathrm{T}_{3}\right)$ in the rat pituitary. Mol. Cell. Endocrinol. 33:281-292.

4. Franklyn, J. A., D. B. Ramsden, and M. C. Sheppard. 1985. Down-regulation of nuclear $T_{3}$ receptors by thyroid hormones in the rat anterior pituitary. Mol. Cell. Endocrinol. 40:145-148.

5. Silva, J. E., and P. R. Larsen. 1978. Contributions of plasma triiodothyronine and local thyroxine monodeiodination to triiodothyronine to nuclear triiodothyronine receptor saturation in pituitary, liver, and kidney of hypothyroid rats. J. Clin. Invest. 61:1247-1249.

6. Hamada, S., H. Nakamura, M. Nanno, and H. Imura. 1979. Triiodothyronine-induced increase in rat liver nuclear thyroid-hormone receptors associated with increased mitochondrial $\alpha$-glycerophosphate dehydrogenase activity. Biochem. J. 182:371-375.

7. Murthy, P. V. N., K. Banovac, and J. M. McKenzie. 1978. Hypothyroidism-induced changes in triiodothyronine binding to nuclei and cytosol-binding proteins in rat liver. Endocrinology. 102:1129-1136.

8. Weinberger, C., C. C. Thompson, E. S. Org, R. Lebo, D. J. Gruol, and R. M. Evans. 1986. The c-erbA gene encodes a thyroid hormone receptor. Nature (Lond.). 324:641-646.

9. Sap, J., A. Munoz, K. Damm, Y. Goldberg, J. Ghysdael, A. Lentz, H. Beug, and B. Vennstrom. 1986. The c-erbA protein is a high affinity receptor for thyroid hormone. Nature (Lond.). 324:635-640.

10. Thompson, C. C., C. Weinberger, R. Lebo, and R. M. Evans. 1987. Identification of a novel thyroid hormone receptor expressed in the mammalian central nervous system. Science (Wash. DC). 237:1610-1614.

11. Benbrook, D., and M. Pfahl. 1987. A novel thyroid hormone receptor encoded by a cDNA clone from a human testis library. Science (Wash. DC). 238:788-791.

12. Izumo, S., and V. Mahdavi. 1988. Thyroid hormone receptor $\alpha$ isoforms generated by alternative splicing differentially activate myosin HC gene transcription. Nature (Lond.). 334:539-542.

13. Koenig, R., R. L. Warne, G. A. Brent, J. W. Harney, P. R Larsen, and D. D. Moore. 1988. Isolation of a cDNA clone encoding a biologically active thyroid hormone receptor. Proc. Natl. Acad. Sci. USA. 85:5031-5035.

14. Lazar, M. A., R. A. Hodin, D. S. Darling, and W. W. Chin. 1988. Identification of a rat c-erbA $\alpha$-related protein which binds DNA but does not bind thyroid hormone. Mol. Endocrinol. 2:893-901.

15. Mitsuhashi, T., G. E. Tennyson, and V. M. Nikodem. 1988. Alternative splicing generates messages encoding rat c-erbA proteins that do not bind thyroid hormone. Proc. Natl. Acad. Sci. USA. 85:5804-5808.

16. Murray, M. B., N. D. Zilz, N. L. McCreary, M. J. MacDonald, and $H$. C. Towle. 1988. Isolation and characterization of rat cDNA clones from two distinct thyroid hormone receptors. J. Biol. Chem. 263:12270-12777.

17. Nakai, A., S. Seino, A. Sakurai, I. Szilak, G. I. Bell, and L. I. deGroot. 1988. Characterization of a thyroid hormone receptor expressed in human kidney and other tissues. Proc. Natl. Acad. Sci. USA. 85:2781-2785.

18. Hodin, R. A., M. A. Lazar, B. I. Wintman, D. S. Darling, R. J. Koenig, P. R. Larsen, D. D. Moore, and W. W. Chin. 1989. Identifcation of a thyroid hormone receptor that is pituitary-specific. Science (Wash. DC). 244:76-79.

19. Lazar, M. A., and W. W. Chin. 1988. Regulation of two c-erbA messenger ribonucleic acids in rat $\mathrm{GH}_{3}$ cells by thyroid hormone. $\mathrm{Mol}$. Endocrinol. 2:479-484.

20. Koenig, R. J., M. A. Lazar, R. A. Hodin, G. A. Brent, P. R. Larsen, W. W. Chin, and D. D. Moore. 1989. Inhibition of thyroid hormone action by a non-hormone binding c-erbA protein generated by alternative mRNA splicing. Nature (Lond.). 337:659-661.

21. Chirgwin, J. M., A. E. Przybla, R. J. MacDonald, and W. J. 
Rutter. 1980. Isolation of biologically active ribonucleic acid from sources enriched in ribonuclease. Biochemistry. 18:5294-5299.

22. Maniatis, T., E. F. Fritsch, and J. Sambrook. 1982. Molecular cloning: A Laboratory Manual. Cold Spring Harbor Laboratory, Cold Spring Harbor, NY. 545 pp.

23. Bradford, M. M. 1976. A rapid and sensitive method for the quantitation of microgram quantities of protein utilizing the principle of protein-dye binding. Anal. Biochem. 72:248-254.

24. Hervas, F., G. Morreale de Escobar, and F. Escobar del Ray. 1975. Rapid effects of single small doses of L-thyroxine and triiodo-Lthyronine on growth hormone, as studied in the rat by radioimmunoassay. Endocrinology. 97:91-101.

25. Schussler, G. C., and J. Orlando. 1978. Fasting decreases triiodothyronine receptor capacity. Science (Wash. DC). 199:686-688.

26. Lefkowitz, R. J. 1981. Receptor Regulation. Chapman and Hall Ltd., London.

27. McDonnell, D. P., D. J. Mangelsdorf, J. W. Pike, M. R. Haussler, and B. W. O'Malley. 1987. Molecular cloning of complementary DNA encoding the avian receptor for vitamin D. Science (Wash. DC). 235:1214-1217.
28. Svec, F. 1985. Minireview: glucocorticoid receptor regulation. Life Sci. 36:2359-2366.

29. Okret, S., L. Poellinger, Y. Dong, and J.-A. Gustafsson. 1986. Down-regulation of glucocorticoid receptor mRNA by glucocorticoid hormones and recognition by the receptor of a specific binding sequence within a receptor cDNA clone. Proc. Natl. Acad. Sci. USA. 83:5899-5903.

30. Saceda, M., M. E. Lippman, P. Chambon, R. L. Lindsey, M. Ponglikitmongkol, M. Puente, and M. S. Martin. 1988. Regulation of the estrogen receptor in MCF-7 cells by estradiol. Mol. Endocrinol. 2:1157-1162.

31. de The, H., A. Marchio, P. Tiollais, and A. Dejean. 1989. Differential expression and ligand regulation of the retinoic acid receptor $\alpha$ and $\beta$ genes. EMBO (Eur. Mol. Biol. Organ.) J. 8:429-433.

32. Shupnik, M. A., M. S. Gordon, and W. W. Chin. 1989. Tissuespecific regulation of rat estrogen receptor mRNAs. Mol. Endocrinol. 3:660-665.

33. Kalinyak, J. E., R. I. Dorin, A. R. Hoffman, and A. J. Perlman. 1987. Tissue-specific regulation of glucocorticoid receptor mRNA by dexamethasone. J. Biol. Chem. 262:10441-10444. 